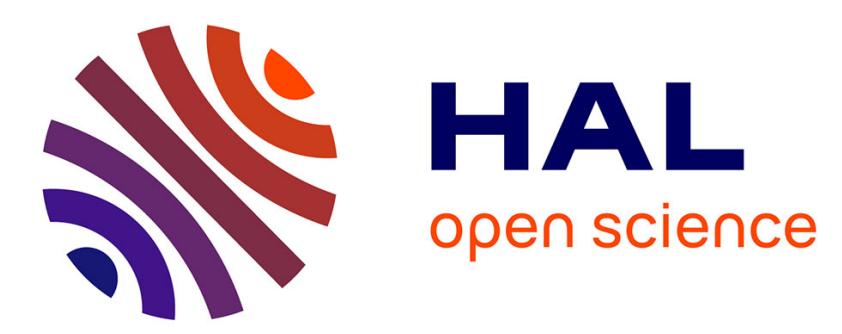

\title{
ADMET polymerization of biobased monomers deriving from syringaresinol
}

Louis Hollande, Abdus Samad Jaufurally, Paul-Henri Ducrot, Florent Allais

\section{To cite this version:}

Louis Hollande, Abdus Samad Jaufurally, Paul-Henri Ducrot, Florent Allais. ADMET polymerization of biobased monomers deriving from syringaresinol. RSC Advances, 2016, 6 (50), pp.44297 - 44304. 10.1039/c6ra06348a . hal-01598621

\section{HAL Id: hal-01598621}

\section{https://hal-agroparistech.archives-ouvertes.fr/hal-01598621}

Submitted on 27 May 2020

HAL is a multi-disciplinary open access archive for the deposit and dissemination of scientific research documents, whether they are published or not. The documents may come from teaching and research institutions in France or abroad, or from public or private research centers.
L'archive ouverte pluridisciplinaire HAL, est destinée au dépôt et à la diffusion de documents scientifiques de niveau recherche, publiés ou non, émanant des établissements d'enseignement et de recherche français ou étrangers, des laboratoires publics ou privés. 


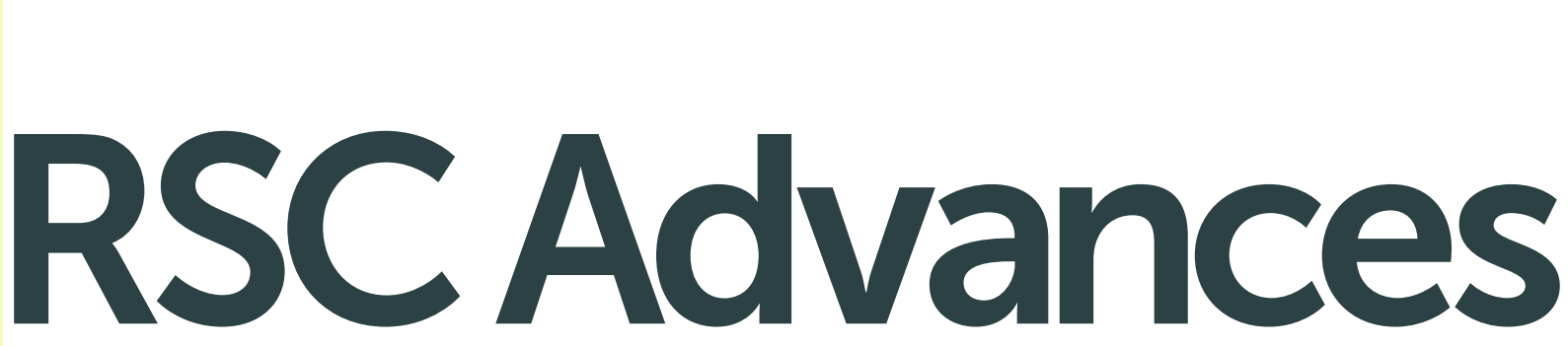

This article can be cited before page numbers have been issued, to do this please use: L. Hollande, A. S. Jaufurally, P. Ducrot and F. Allais, RSC Adv., 2016, DOI: 10.1039/C6RA06348A.
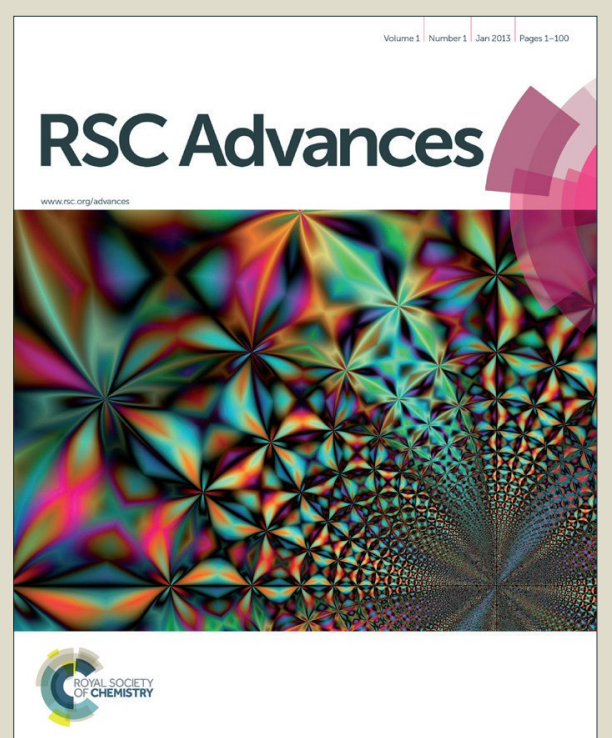

This is an Accepted Manuscript, which has been through the Royal Society of Chemistry peer review process and has been accepted for publication.

Accepted Manuscripts are published online shortly after acceptance, before technical editing, formatting and proof reading. Using this free service, authors can make their results available to the community, in citable form, before we publish the edited article. This Accepted Manuscript will be replaced by the edited, formatted and paginated article as soon as this is available.

You can find more information about Accepted Manuscripts in the Information for Authors.

Please note that technical editing may introduce minor changes to the text and/or graphics, which may alter content. The journal's standard Terms \& Conditions and the Ethical guidelines still apply. In no event shall the Royal Society of Chemistry be held responsible for any errors or omissions in this Accepted Manuscript or any consequences arising from the use of any information it contains. 


\title{
ADMET polymerization of biobased monomers deriving from syringaresinol
}

\author{
Louis Hollande ${ }^{\S a}$, Abdus Samad Jaufurally ${ }^{\S a, b}$, Paul-Henri Ducrot ${ }^{\text {b* }}$, Florent Allais ${ }^{a, c *}$

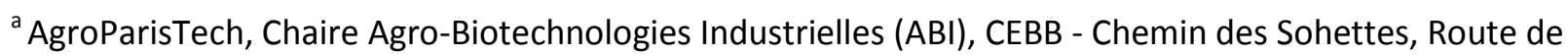 \\ Bazancourt, F-51110 Pomacle, France \\ ${ }^{\mathrm{b}}$ Institut Jean-Pierre Bourgin, INRA, AgroParisTech, CNRS, Université Paris-Saclay, RD10, 78026 Versailles \\ Cedex, France \\ ' UMR 782 GMPA, INRA, AgroParisTech, CNRS, Université Paris-Saclay, Avenue Lucien Brétignières F- \\ 78850 Thiverval-Grignon, France \\ ${ }^{\S}$ These authors contributed equally to this work
}

Correspondence to: Prof. F. Allais (florent.allais@agroparistech.fr), Dr. Paul-Henri Ducrot (ducrot@versailles.inra.fr)

Additional Supporting Information may be found in the online version of this article.

\begin{abstract}
Renewable $\alpha, \omega$-dienes have been prepared from syringaresinol, a naturally occurring bisphenol deriving from sinapyl alcohol, and further studied as monomers in ADMET polymerizations. Polymerization was optimized according to catalyst loading and reaction conditions (in mass vs. in solvent), and led to polymers with molecular weight up to $14.1 \mathrm{kDa}$. Thermal analyses of these new polymers showed excellent thermal stabilities $\left(257-360^{\circ} \mathrm{C}\right)$ and tunable $T_{g}\left(18-70^{\circ} \mathrm{C}\right)$ depending on the structure of the starting $\alpha, \omega$-diene monomer.
\end{abstract}

KEYWORDS: ADMET polymerization, syringaresinol, bisphenol

\section{INTRODUCTION}

The collapse of fossil resources and rising prices may have been the first trigger for a biobased economy. Nevertheless, today, industries, customers and regulators (e.g., REACH) are increasingly demanding for eco-friendly and bio-based chemicals issued from sustainable industrial processes. In this context, the production of new platform chemicals from biomass through green processes is an alluring strategy for a sustainable development. Indeed, biomass offers a wide range of molecules that can be used to access valuable synthons such as polyols, furans, fatty acids, aliphatic alkanes/alkenes or aromatics/phenolics to name a few. ${ }^{1}$ Out of these sustainable and valuable chemical feedstocks, sinapic acid, from the ancient greek oivari (sinapi), a major compound isolated from Brassicaceae seeds and also one of the three major $p$-hydroxycinnamic acids found in lignocellulosic biomass, is one of the most promising substitute to fossil phenolics. It is present in relatively large quantities in the form of sinapine (choline ester of sinapic acid) in the seeds of oil plants from the Brassicaceae family. ${ }^{2}$

In order to offer some new opportunities of valorization of this compound, and having dedicated ourselves to the synthesis and valorization of lignin-derived phenolics and more particularly $p$-hydroxycinnamic acids and derivatives, ${ }^{3-14}$ we recently optimized a chemoenzymatic synthetic pathway allowing the 
synthesis of syringaresinol from sinapic acid (or syringaldehyde) in very high yield and purity. ${ }^{15}$ The work reported here presents the use of syringaresinol as precursor for the synthesis of novel $\alpha, \omega$-dienes monomers incorporating the two aromatic rings of syringaresinol linked through a cis-fused bisfuranic moiety. These monomers were then submitted to acyclic diene metathesis (ADMET) polymerization.

Indeed, thanks to the ease of handling and high functional group tolerance of the Ru-based catalysts used in ADMET, this method is a very useful approach for the construction of well defined polymer architectures ${ }^{16}$ and allowed the synthesis of renewable polymers, such as polyesters, polyethers, polyamides and many others, very promising for commercial applications. ${ }^{12,17-27}$ In spite of extensive research to develop commercial ferulic acid-, ${ }^{12,17}$ eugenol- ${ }^{22}$ vanillin- ${ }^{23}$ and bisvanillin- ${ }^{24}$ renewable polymers, to the best of our knowledge, there is no example of ADMET polymerization involving sinapic acid derivatives (i.e., syringaresinol, syringaldehyde) as diene substrates.

The structure and thermal properties of these novel polymers were thereafter studied in order to evaluate their potential in industrial applications.

\section{EXPERIMENTAL}

\section{Materials and methods}

All reagents were purchased from Sigma-Aldrich or Tokyo Chemical Industry Co and used as received. Solvents were purchased from ThermoFisher Scientific, DMF was dried on a mBraun SPS 800 system. Deuterated chloroform $\left(\mathrm{CDCl}_{3}\right)$ was purchased from Eurisotop. Evaporations were conducted under reduced pressure at temperature below $40{ }^{\circ} \mathrm{C}$. Column chromatographies were carried out with an automated flash chromatography (PuriFlash 4100, Interchim) and pre-packed INTERCHIM PF-30SI-HP (30 $\mu \mathrm{m}$ silica gel) columns. FT-IR and UV analyses were performed on Cary 630 FTIR and Cary 60 UV-Vis from Agilent technologies, respectively. NMR analyses were recorded on a Bruker Fourier 300. ${ }^{1} \mathrm{H}$ NMR spectra of samples were recorded in $\mathrm{CDCl}_{3}$ at $300 \mathrm{MHz}$ (residual $\mathrm{CHCl}_{3}$ signal at $\delta=$ $7.26 \mathrm{ppm}$ ). ${ }^{13} \mathrm{C}$ NMR spectra of samples were recorded at $75 \mathrm{MHz}\left(\mathrm{CDCl}_{3}\right.$ signal at $\delta=77.16$ ppm). Thermo-gravimetric analyses (TGA) were recorded on a Q500, from TA. Around $5 \mathrm{mg}$ of each sample was heated at $10^{\circ} \mathrm{C} \cdot \mathrm{min}^{-1}$ from 50 to $500{ }^{\circ} \mathrm{C}$ under nitrogen flow $\left(60 \mathrm{~mL} \cdot \mathrm{min}^{-1}\right)$. Differential scanning calorimetry (DSC) thermograms were obtained using a DSC Q20, from $T A$, under inert atmosphere $\left(\mathrm{N}_{2}\right)$. Around 5 $\mathrm{mg}$ were weighed in a pan which was then sealed and submitted to the following heat/cool/heat cycle: equilibration at $-60{ }^{\circ} \mathrm{C}$ and hold for $5 \mathrm{~min}$, heating from $-60{ }^{\circ} \mathrm{C}$ to 200 ${ }^{\circ} \mathrm{C}$ at $10{ }^{\circ} \mathrm{C} \cdot \mathrm{min}^{-1}$ and hold for $5 \mathrm{~min}$, cooling from $200{ }^{\circ} \mathrm{C}$ to $-60{ }^{\circ} \mathrm{C}$ at $10{ }^{\circ} \mathrm{C} \cdot \mathrm{min}^{-1}$. Gel Permeation Chromatography (GPC) was performed at $40{ }^{\circ} \mathrm{C}$ on an Infinity 1260 system from Agilent Technologies with a quadruple detection (IR, UV, MALS, viscosimetry) and two PL-Gel $5 \mathrm{~mm}$ Mixed D column (300 mm $\times 7.5$ $\mathrm{mm}$ ) in THF (flow rate $1 \mathrm{~mL} \cdot \mathrm{min}^{-1}$ ) using polystyrene calibration. HRMS were recorded by the PLANET platform at URCA on a Micromass GC-TOF.

\section{Synthesis of (+/-)-syringaresinol}

Sinapyl alcohol (4 g, $19 \mathrm{mmol}, 1 \mathrm{eq}$ ) was dissolved in acetonitrile $(80 \mathrm{~mL})$ in a triple-neck round bottom flask equipped with a cooling system and citrate/phosphate buffer $(320 \mathrm{~mL})$ at $\mathrm{pH} 5$ were added $(0.05 \mathrm{M})$. A solution containing $35.2 \mathrm{mg}$ of laccase from Trametes versicolor $(0.1 \mathrm{U} / \mathrm{mg}$ of substrate) in $50 \mathrm{~mL}$ of citrate/phosphate buffer was added dropwise to the monolignol solution at a rate of 9 $\mathrm{mL} /$ hour with a syringe pump. The reaction mixture was stirred with a magnetic stirrer in the presence of $\mathrm{O}_{2}$ (air) at $50{ }^{\circ} \mathrm{C}$ for $470 \mathrm{~min}$ in darkness. At the end of the reaction, the product was extracted with dichloromethane $(2$ $x 150 \mathrm{~mL})$ and ethyl acetate $(2 \times 150 \mathrm{~mL})$. The 
organic phases were combined, dried over anhydrous $\mathrm{MgSO}_{4}$, filtered and the solvent was evaporated under reduced pressure and no further purification was needed.

White powder (93\%). Mp: $169^{\circ} \mathrm{C}$. FT-IR (neat): $v_{\max } 3424(\mathrm{OH}), 1400-1600(\mathrm{Ar}), 1000-1300$ (CO-C). HRMS: (TOF MS, ES+): $\mathrm{m} / \mathrm{z}$ calcd for $\mathrm{C}_{22} \mathrm{H}_{26} \mathrm{O}_{8} \mathrm{Na}$ : 441.1525; found: 441.1516. ${ }^{1} \mathrm{H}$ NMR (300 MHz, CDCl 3 , ס): $3.10\left(\mathrm{~m}, 2 \mathrm{H}, \mathrm{H}_{\beta}\right), 3.90$ $\left(\mathrm{s}, 12 \mathrm{H}, \mathrm{H}_{5}\right), 3.90\left(\mathrm{~m}, 2 \mathrm{H}, \mathrm{H}_{\mathrm{\gamma}}\right), 4.27(\mathrm{dd}, 2 \mathrm{H}, \mathrm{J}=6.9$ $\mathrm{Hz}$ and $\left.9.0 \mathrm{~Hz}, \mathrm{H}_{\mathrm{\gamma}^{\prime}}\right), 4.73\left(\mathrm{~d}, 2 \mathrm{H}, J=4.2 \mathrm{~Hz}, \mathrm{H}_{\alpha}\right)$, $5.51\left(\mathrm{~s}, 2 \mathrm{H}, \mathrm{H}_{\text {phenol }}\right), 6.59\left(\mathrm{~s}, 4 \mathrm{H}, \mathrm{H}_{2}\right) .{ }^{13} \mathrm{C}$ NMR $(75$ $\left.\mathrm{MHz}, \mathrm{CDCl}_{3}, \delta\right): 54.4\left(\mathrm{C}_{\beta}\right), 56.4\left(\mathrm{C}_{5}\right), 71.8\left(\mathrm{C}_{\gamma}\right)$, $86.1\left(C_{\alpha}\right), 102.7\left(C_{2}\right), 132.1\left(C_{1}\right), 134.3\left(C_{4}\right), 147.2$ $\left(C_{3}\right)$

\section{General procedure for the synthesis of $\alpha, \omega$ - diene monomers}

Syringaresinol ( 1 equiv) and $\mathrm{K}_{2} \mathrm{CO}_{3}$ (5 equiv) were dissolved in dry DMF $(2 \mathrm{M})$ under nitrogen. Bromo-alkene (4 equiv) was then added, and the mixture was stirred and heated at $80{ }^{\circ} \mathrm{C}$ for $12 \mathrm{~h}$. Reaction was quenched with water $\left(\mathrm{v}\left(\mathrm{H}_{2} \mathrm{O}\right)=\mathrm{v}(\mathrm{DMF})\right)$ and the aqueous layer was extracted three times with ethyl acetate (3 $\left.x \mathrm{v}\left(\mathrm{H}_{2} \mathrm{O}\right)\right)$. Organic layers were combined, washed with brine, dried over anhydrous $\mathrm{MgSO}_{4}$, filtered and concentrated. Crude product was purified by flash chromatography on silica gel Cyclohexane:AcOEt (from 95/5 to $50 / 50)$ to yield the corresponding $\alpha, \omega$-diene monomer.

Bis-Allyl-O-syringaresinol (SYR-All)

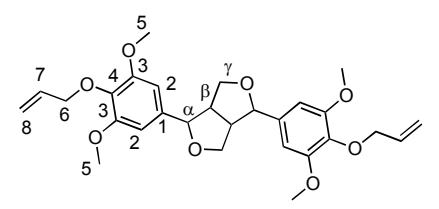

White powder (75\%). FTIR (neat): $v_{\max }: 1501 \quad(\mathrm{C}=\mathrm{C}$ Ar). HRMS: (TOF

MS, ES $\left.{ }^{+}\right): m / z$ calcd for $\mathrm{C}_{28} \mathrm{H}_{34} \mathrm{O}_{8} \mathrm{Na}[\mathrm{MNa}]^{+}$: 521.2151; found: 521.2142. ${ }^{1} \mathrm{H}$ NMR $(300 \mathrm{MHz}$, $\left.\mathrm{CDCl}_{3}, \delta\right): 3.10\left(\mathrm{~m}, 2 \mathrm{H}, \mathrm{H}_{\beta}\right), 3.85\left(\mathrm{~s}, 12 \mathrm{H}, \mathrm{H}_{5}\right)$, $3.91\left(\mathrm{dd}, 2 \mathrm{H}, J=3.6 \mathrm{~Hz} \mathrm{H}_{\mathrm{\gamma}}\right), 4.33\left(\mathrm{~m}, 2 \mathrm{H}, \mathrm{H}_{\mathrm{y}^{\prime}}\right)$, $4.48\left(\mathrm{~d}, 4 \mathrm{H}, J=7 \mathrm{~Hz}, \mathrm{H}_{6}\right), 4.73(\mathrm{~d}, 2 \mathrm{H}, J=4 \mathrm{~Hz}$, $\left.\mathrm{H}_{\alpha}\right), 5.15\left(\mathrm{~m}, 2 \mathrm{H}, \mathrm{H}_{8}\right), 5.32\left(\mathrm{~m}, 2 \mathrm{H}, \mathrm{H}_{8}\right), 6.10(\mathrm{~m}$, $\left.2 \mathrm{H}, \mathrm{H}_{7}\right), 6.58\left(\mathrm{~s}, 4 \mathrm{H}, \mathrm{H}_{2}\right) .{ }^{13} \mathrm{C} \mathrm{NMR}(75 \mathrm{MHz}$, $\left.\mathrm{CDCl}_{3}, \delta\right): 54.6\left(\mathrm{C}_{\beta}\right), 57.3\left(\mathrm{C}_{5}\right), 71.9\left(\mathrm{C}_{6}\right), 74.2$ $\left(C_{\gamma, \gamma^{\prime}}\right), 85.9\left(C_{\alpha}\right), 102.87\left(C_{2}\right), 117.7\left(C_{8}\right), 134.5$ $\left(C_{7}\right), 136.1\left(C_{1}\right), 136.7\left(C_{4}\right), 153.63\left(C_{3}\right)$.

Bis-Butene-O-syringaresinol (SYR-But)

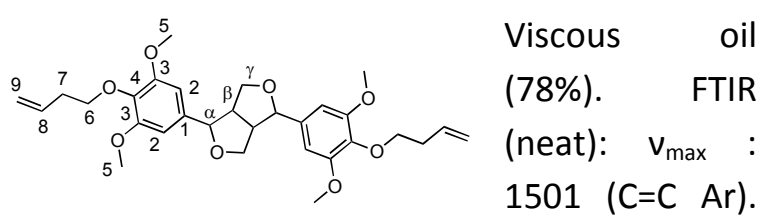

HRMS: (TOF MS, ES ${ }^{+}$): $\mathrm{m} / z$ calcd for $\mathrm{C}_{30} \mathrm{H}_{38} \mathrm{O}_{8} \mathrm{Na}$ $[\mathrm{MNa}]^{+}$: 549.2464; found: 549.2474. ${ }^{1} \mathrm{H}$ NMR (300 MHz, $\mathrm{CDCl}_{3}, \delta$ ): 2.49 (q, $4 \mathrm{H}, J=6.9 \mathrm{~Hz}$ and $\left.13.8 \mathrm{~Hz}, \mathrm{H}_{7}\right), 3.10\left(\mathrm{~m}, 2 \mathrm{H}, \mathrm{H}_{\beta}\right), 3.84\left(\mathrm{~s}, 12 \mathrm{H}, \mathrm{H}_{5}\right)$, $3.90\left(\mathrm{~m}, 2 \mathrm{H}, J=3.6 \mathrm{~Hz}, \mathrm{H}_{\mathrm{\gamma}}\right), 3.99(\mathrm{t}, 4 \mathrm{H}, J=7,2$ $\left.\mathrm{Hz}, \mathrm{H}_{6}\right), 4.30\left(\mathrm{~m}, 2 \mathrm{H}, \mathrm{H}_{\mathrm{\gamma}^{\prime}}\right), 4.72(\mathrm{~d}, 2 \mathrm{H}, J=4 \mathrm{~Hz}$, $\left.\mathrm{H}_{\alpha}\right), 5.09\left(\mathrm{~m}, 4 \mathrm{H}, \mathrm{H}_{9}\right), 5.87\left(\mathrm{~m}, 2 \mathrm{H}, \mathrm{H}_{8}\right), 6.6(\mathrm{~s}, 4 \mathrm{H}$, $\mathrm{H}_{2}$ ). ${ }^{13} \mathrm{C} \mathrm{NMR}\left(75 \mathrm{MHz} \mathrm{CDCl}_{3}, \delta\right): 34.5\left(\mathrm{C}_{7}\right), 54.3$ $\left(C_{\beta}\right), 56.2\left(C_{5}\right), 71.9\left(C_{6}\right), 72.4\left(C_{\gamma, \gamma^{\prime}}\right), 86.0\left(C_{\alpha}\right)$, $102.9\left(C_{2}\right), 116.4\left(C_{9}\right), 134.9\left(C_{8}\right), 136.6\left(C_{4,1}\right)$, $153.6\left(C_{3}\right)$.

Bis-Hexene-O-syringaresinol (SYR-Hex)

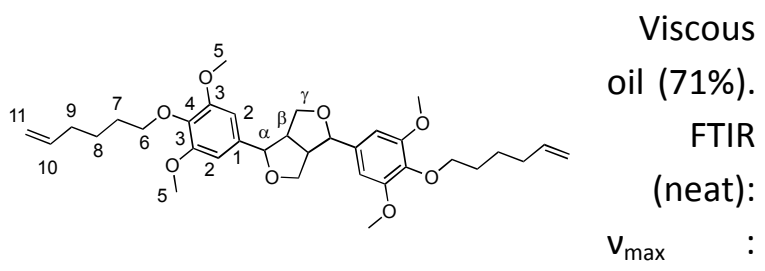

1501 ( $C=C$ Ar). HRMS: (TOF MS, ES ${ }^{+}$): $m / z$ calcd for $\mathrm{C}_{34} \mathrm{H}_{46} \mathrm{O}_{8} \mathrm{Na} \quad[\mathrm{MNa}]^{+}$: 605.3090; found: 605.3098. ${ }^{1} \mathrm{H}$ NMR (300 MHz, $\left.\mathrm{CDCl}_{3}, \delta\right): 1.54(\mathrm{~m}$, $\left.4 \mathrm{H}, \mathrm{H}_{8}\right), 1.7$ (qt, $\left.4 \mathrm{H}, J=6.9 \mathrm{~Hz}, \mathrm{H}_{7}\right), 2.1$ (q, $4 \mathrm{H}, J=$ $\left.7.2 \mathrm{~Hz}, \mathrm{H}_{9}\right), 3.11\left(\mathrm{~m}, 2 \mathrm{H}, \mathrm{H}_{\beta}\right), 3.84\left(\mathrm{~s}, 12 \mathrm{H}, \mathrm{H}_{5}\right)$, $3.84\left(\mathrm{~m}, 2 \mathrm{H}, \mathrm{H}_{\mathrm{\gamma}}\right), 3.93\left(\mathrm{~m}, 4 \mathrm{H}, \mathrm{H}_{6}\right), 4.31(\mathrm{~m}, 2 \mathrm{H}$, $\left.\mathrm{H}_{\mathrm{\gamma}^{\prime}}\right), 4.73\left(\mathrm{~d}, 2 \mathrm{H}, J=4.2 \mathrm{~Hz}, \mathrm{H}_{\alpha}\right), 4.94-5.04(\mathrm{~m}$, $\left.4 \mathrm{H}, \mathrm{H}_{11}\right), 5.84\left(\mathrm{~m}, 2 \mathrm{H}, \mathrm{H}_{10}\right), 6.58\left(\mathrm{~s}, 4 \mathrm{H}, \mathrm{H}_{2}\right) .{ }^{13} \mathrm{C}$ NMR (75 MHz, $\left.\mathrm{CDCl}_{3}, \delta\right): 25.1\left(\mathrm{C}_{8}\right), 29.5\left(\mathrm{C}_{7}\right)$, $33.5\left(C_{9}\right), 54.3\left(C_{\beta}\right), 56.2\left(C_{5}\right), 71.9\left(C_{6}\right), 73.21$ 
$\left(C_{\gamma, \gamma^{\prime}}\right), 86.0\left(C_{\alpha}\right), 103.0\left(C_{2}\right), 114.41\left(C_{11}\right), 136.4$ $\left(C_{1}\right), 136.8\left(C_{4}\right), 138.9\left(C_{10}\right), 153.7\left(C_{3}\right)$.

Bis-Decene-O-syringaresinol (SYR-Dec)

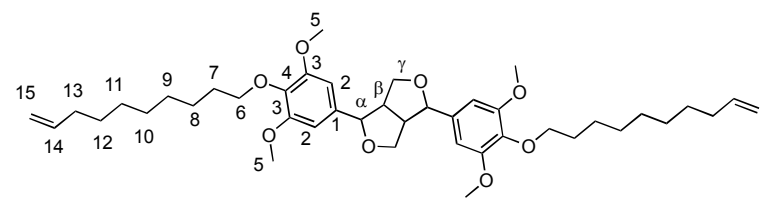

Viscous oil (77\%). FTIR (neat): $v_{\max }: 1502$ (C=C Ar). HRMS: (TOF MS, $\mathrm{ES}^{+}$): $\mathrm{m} / \mathrm{z}$ calcd for $\mathrm{C}_{42} \mathrm{H}_{62} \mathrm{O}_{8} \mathrm{Na}$ [MNa] $]^{+}$: 717.4342; found: 717.4351.

${ }^{1} \mathrm{H}$ NMR (300 MHz, $\left.\mathrm{CDCl}_{3}, \delta\right): 1.30-1.44(\mathrm{~m}$, $20 \mathrm{H}, \mathrm{H}_{8,9,10,11,12}$ ), 1.73 (qt, $4 \mathrm{H}, J=7.8 \mathrm{~Hz}, \mathrm{H}_{7}$ ), $2.02\left(\mathrm{q}, 4 \mathrm{H}, J=7.1 \mathrm{~Hz}, \mathrm{H}_{13}\right), 3.1\left(\mathrm{~m}, 2 \mathrm{H}, \mathrm{H}_{\beta}\right), 3.83$ $\left(\mathrm{s}, 12 \mathrm{H}, \mathrm{H}_{5}\right), 3.92\left(\mathrm{~m}, 6 \mathrm{H}, \mathrm{H}_{\mathrm{y}, 6}\right), 4.29\left(\mathrm{~m}, 2 \mathrm{H}, \mathrm{H}_{\mathrm{y}^{\prime}}\right)$, $4,72\left(\mathrm{~d}, 2 \mathrm{H}, J=4.2 \mathrm{~Hz}, \mathrm{H}_{\alpha}\right), 4.89-5.28(\mathrm{~m}, 4 \mathrm{H}$, $\left.\mathrm{H}_{15}\right), 5.75\left(\mathrm{~m}, 2 \mathrm{H}, \mathrm{H}_{14}\right), 6.55\left(\mathrm{~s}, 4 \mathrm{H}, \mathrm{H}_{2}\right) .{ }^{13} \mathrm{C} N M R$ (75 $\mathrm{MHz}_{2} \mathrm{CDCl}_{3}, \delta$ ): $25.8\left(\mathrm{C}_{8}\right), 28.9-30.1$ $\left(C_{7,9,10,11,12}\right), 33.8\left(C_{13}\right), 54.3\left(C_{\beta}\right), 56.1\left(C_{5}\right)$, $71.9\left(C_{6}\right), 73.51\left(C_{\gamma, \gamma^{\prime}}\right), 86.0\left(C_{\alpha}\right), 103.0\left(C_{2}\right), 114.1$ $\left(C_{15}\right), 136.3\left(C_{1}\right), 136.9\left(C_{4}\right), 139.2\left(C_{14}\right), 153.7$ $\left(C_{3}\right)$.

\section{General Procedure for ADMET polymerizations}

\section{Mass polymerizations}

Monomer (500 mg) and $p$-benzoquinone (2 eq. relative to Hoveyda-Grubbs II catalyst) were stirred at $100{ }^{\circ} \mathrm{C}$, under vacuum for $5 \mathrm{~min}$. Hoveyda-Grubbs II catalyst (0.1-10 mol\%) was added and the reaction was continued, under vacuum, for $4 \mathrm{~h}$ at $100{ }^{\circ} \mathrm{C}$. Reaction was quenched with $1 \mathrm{~mL}$ of THF and 4 drops of vinyl ethyl ether. Product was concentrated and further dissolved in THF $(1 \mathrm{~mL})$ and precipitated in cold methanol (50 mL).

\section{Solvent polymerization}

Monomer ( 1 eq.) and $p$-benzoquinone ( 2 eq. relative to Hoveyda-Grubbs II catalyst) were dissolved in dry DCM (2 M). Hoveyda-Grubbs II catalyst (1-10 mol\%) was added and the reaction was stirred, under nitrogen, at $40{ }^{\circ} \mathrm{C}$ for $4 \mathrm{~h}$. Reaction was quenched with $1 \mathrm{~mL}$ of THF and 4 drops of vinyl ethyl ether. Product was concentrated and a sample was taken for GPC analyses. The remainder was dissolved in THF $(1 \mathrm{~mL})$ and precipitated in cold methanol $(50 \mathrm{~mL})$.

Polymer obtained from SYR-All (P1) (1 mol\% HG-II, 2 mol\% 1,4-benzoquinone, $\left.100{ }^{\circ} \mathrm{C}\right):{ }^{1} \mathrm{H}$ $\operatorname{NMR}\left(300 \mathrm{MHz}, \mathrm{CDCl}_{3}, \delta\right): 3.10\left(\mathrm{~m}, 2 \mathrm{H}, \mathrm{H}_{\beta}\right), 3.84$ $\left(\mathrm{s}, 12 \mathrm{H}, \mathrm{H}_{5}\right), 3.90\left(\mathrm{~m}, 2 \mathrm{H}, \mathrm{H}_{\mathrm{y}}\right), 4.30\left(\mathrm{~m}, 2 \mathrm{H}, \mathrm{H}_{\mathrm{y}^{\prime}}\right)$, $4.49\left(\mathrm{~m}, 4 \mathrm{H}, \mathrm{H}_{6}\right), 4.74\left(\mathrm{~m}, 2 \mathrm{H}, \mathrm{H}_{\alpha}\right), 6.05(\mathrm{~m}, 2 \mathrm{H}$, $\left.\mathrm{H}_{7}\right), 6.58\left(\mathrm{~s}, 4 \mathrm{H}, \mathrm{H}_{2}\right) .{ }^{13} \mathrm{C} \mathrm{NMR}\left(75 \mathrm{MHz}, \mathrm{CDCl}_{3}, \delta\right)$ : $54.7\left(C_{\beta}\right), 56.6\left(C_{5}\right), 72.3\left(C_{6}\right), 73.5\left(C_{\gamma}\right), 86.3$ $\left(C_{\alpha}\right), 103.2\left(C_{2}\right), 130.2\left(C_{7}\right), 136.6\left(C_{1}\right), 137.1$ $\left(C_{4}\right), 153.9\left(C_{3}\right)$.

Polymer obtained from SYR-But (P2) (1 mol\% HG-II, 2 mol\% 1,4-benzoquinone, $\left.100{ }^{\circ} \mathrm{C}\right):{ }^{1} \mathrm{H}$ $\operatorname{NMR}\left(300 \mathrm{MHz} \mathrm{CDCl}_{3}, \delta\right): 2.47\left(\mathrm{~m}, 4 \mathrm{H}, \mathrm{H}_{7}\right), 3.10$ $\left(\mathrm{m}, 2 \mathrm{H}, \mathrm{H}_{\beta}\right), 3.83\left(\mathrm{~s}, 12 \mathrm{H}, \mathrm{H}_{5}\right), 3.95\left(\mathrm{~m}, 6 \mathrm{H}, \mathrm{H}_{\mathrm{r}, 6}\right)$, $4.29\left(\mathrm{~m}, 2 \mathrm{H}, \mathrm{H}_{\gamma^{\prime}}\right), 4.72\left(\mathrm{~d}, 2 \mathrm{H}, J=2.7 \mathrm{~Hz}, \mathrm{H}_{\alpha}\right)$, $5.60\left(\mathrm{~m}, 2 \mathrm{H}, \mathrm{H}_{8}\right), 6.55\left(\mathrm{~s}, 4 \mathrm{H}, \mathrm{H}_{2}\right) .{ }^{13} \mathrm{C}$ NMR $(75$ $\left.\mathrm{MHz}, \mathrm{CDCl}_{3}, \delta\right): 34.4\left(\mathrm{C}_{7}\right), 54.3\left(\mathrm{C}_{\beta}\right), 56.2\left(\mathrm{C}_{5}\right)$, $71.9\left(C_{6}\right), 72.9\left(C_{\gamma}\right), 86.0\left(C_{\alpha}\right), 102.9\left(C_{2}\right), 128,2$ $\left(C_{8}\right), 136.6\left(C_{4,1}\right), 153.6\left(C_{3}\right)$.

Polymer obtained from SYR-Hex (P3) (1 mol\% HG-II, 2 mol\% 1,4-benzoquinone, $\left.100{ }^{\circ} \mathrm{C}\right):{ }^{1} \mathrm{H}$ NMR (300 MHz, $\left.\mathrm{CDCl}_{3}, \delta\right): 1.50\left(\mathrm{~m}, 4 \mathrm{H}, \mathrm{H}_{8}\right), 1.71$ $\left(m, 4 \mathrm{H}, \mathrm{H}_{7}\right), 2.03\left(\mathrm{~m}, 4 \mathrm{H}, \mathrm{H}_{9}\right), 3.10\left(\mathrm{~m}, 2 \mathrm{H}, \mathrm{H}_{\beta}\right)$, $3.83\left(\mathrm{~s}, 12 \mathrm{H}, \mathrm{H}_{5}\right), 3.95\left(\mathrm{~m}, 6 \mathrm{H}, \mathrm{H}_{\mathrm{r}, 6}\right), 4.29(\mathrm{~m}, 2 \mathrm{H}$, $\left.\mathrm{H}_{\gamma^{\prime}}\right), 4.73\left(\mathrm{~d}, 2 \mathrm{H}, J=3,9 \mathrm{~Hz}, \mathrm{H}_{\alpha}\right), 5.43(\mathrm{~m}, 2 \mathrm{H}$, $\left.\mathrm{H}_{10}\right), 6.55\left(\mathrm{~s}, 4 \mathrm{H}, \mathrm{H}_{2}\right) \cdot{ }^{13} \mathrm{C} \mathrm{NMR}\left(75 \mathrm{MHz}, \mathrm{CDCl}_{3}\right.$, ठ): $25.9\left(C_{8}\right), 29.7\left(C_{7}\right), 32.4\left(C_{9}\right), 54.4\left(C_{\beta}\right), 56.4$ $\left(C_{5}\right), 72.0\left(C_{6}\right), 73.4\left(C_{y}\right), 86.1\left(C_{\alpha}\right), 103.1\left(C_{2}\right)$, $130.4\left(C_{10}\right), 136.5\left(C_{1}\right), 137.0\left(C_{4}\right), 153.7\left(C_{3}\right)$.

Polymer obtained from SYR-Dec (P4) P4 being slightly soluble, we were not able to get acceptable ${ }^{1} \mathrm{H}$ and ${ }^{13} \mathrm{C}$ NMR spectrum. 

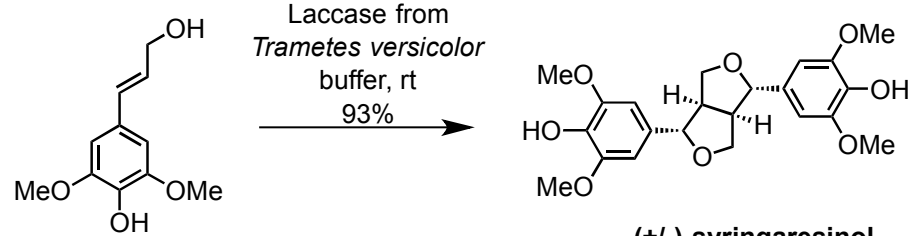

(+/-)-syringaresinol

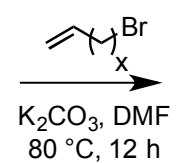
$80^{\circ} \mathrm{C}, 12 \mathrm{~h}$

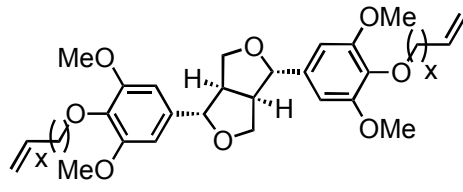

SYR-All $(x=1) 75 \%$ SYR-But $(x=2) 78 \%$ SYR-Hex $(x=4) 71 \%$ SYR-Dec $(x=8) 77 \%$

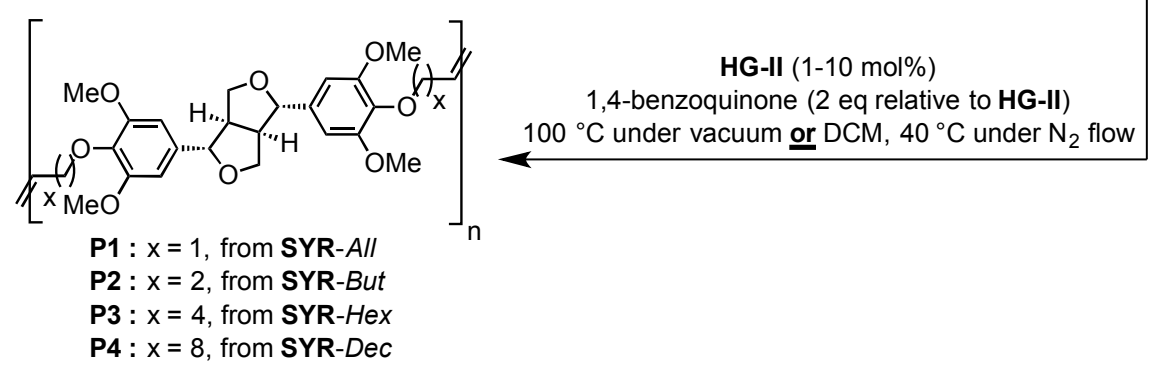

Scheme 1. Synthesis and ADMET polymerization of the four syringaresinol derived $\alpha, \omega$-diene monomers

\section{RESULTS AND DISCUSSION}

$\alpha, \omega$-diene monomers SYR-All, SYR-But, SYRHex and SYR-Dec were prepared by conducting Williamson etherification of syringaresinol with four bromo-alkenes (3-bromoprop-1-ene, 4, bromobut-1-ene, 6-bromohex-1-ene and 10bromodec-1-ene) in DMF at $80^{\circ} \mathrm{C}$, for 12 hours under nitrogen, in presence of potassium carbonate (Scheme 1). These four $\alpha, \omega$-diene monomers were used to study the impact of the chain length of the olefin on the polymerizations and the thermal properties of the resulting polymers.

\section{ADMET polymerization}

We first studied the reactivity of the four syringaresinol-derived $\alpha, \omega$-diene in ADMET polymerization. Though it has been reported that ADMET polymerizations are favored when carried out under bulk conditions (aka in mass), ${ }^{28,12}$ we also performed polymerizations in solvent to verify if this also applied to syringaresinol-based $\alpha, \omega$-diene monomers (Scheme 1). For ADMET reactions conducted in mass at $100{ }^{\circ} \mathrm{C}$, continuous vacuum (ca. 20 mbar) was applied to guarantee the efficient removal of ethylene and thus shift the equilibrium towards polymerization. The latter temperature was chosen as it has been already shown that, in the ADMET polymerization of rigid IDF-based $\alpha, \omega$-dienes ${ }^{12}$ incorporating two dihydroferulate esters of isosorbide, heating the reaction mixture at $100{ }^{\circ} \mathrm{C}$ significantly improves the molecular weights by lowering the viscosity of the reaction medium thus facilitating both ethylene removal and stirring. Dichloromethane, previously reported as a suitable solvent for ADMET, ${ }^{29}$ was used for in solvent polymerizations. Solvent reactions were performed at $40{ }^{\circ} \mathrm{C}$ under a low and steady nitrogen flow to remove ethylene but not dichloromethane. In both reaction conditions, 1,4-benzoquinone ( 2 eq. relative to catalyst) was used to limit olefin isomerization. ${ }^{30}$ Finally, Hoveyda-Grubbs second generation catalyst (HG-II), with loadings varying from 0.1 to 10 mol\%, was the only catalyst tested in this study as previous works by Abbas, $^{31}$ Firdaus $^{23}$ and Barbara $^{12}$ have shown HG-II to be the most active towards the cross metathesis 


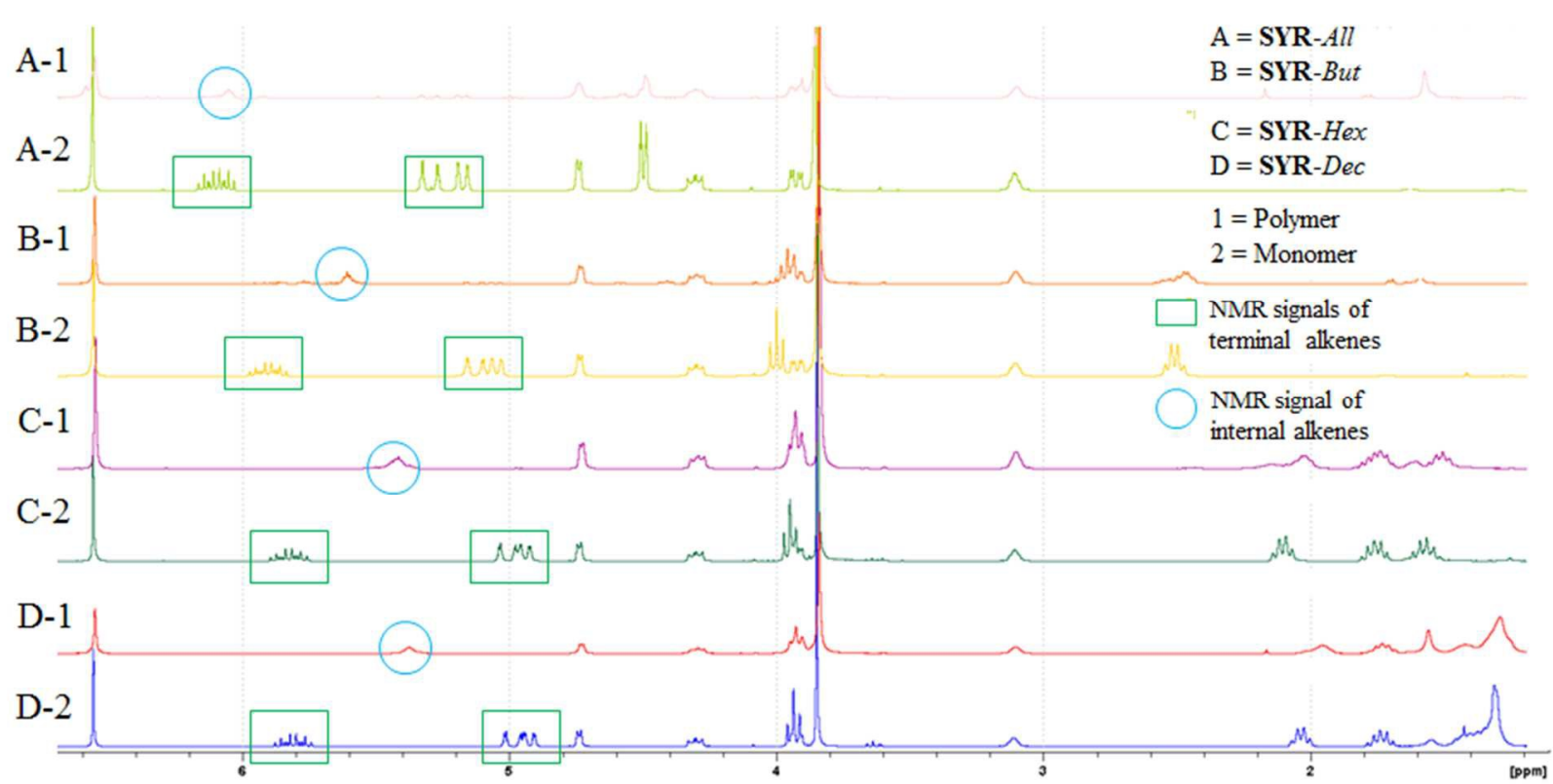

Figure 1. ${ }^{1} \mathrm{H}$ NMR spectra of SYR-All, SYR-But, SYR-Hex and SYR-Dec and their corresponding oligomers and polymers (P1, P2, P3 and P4)

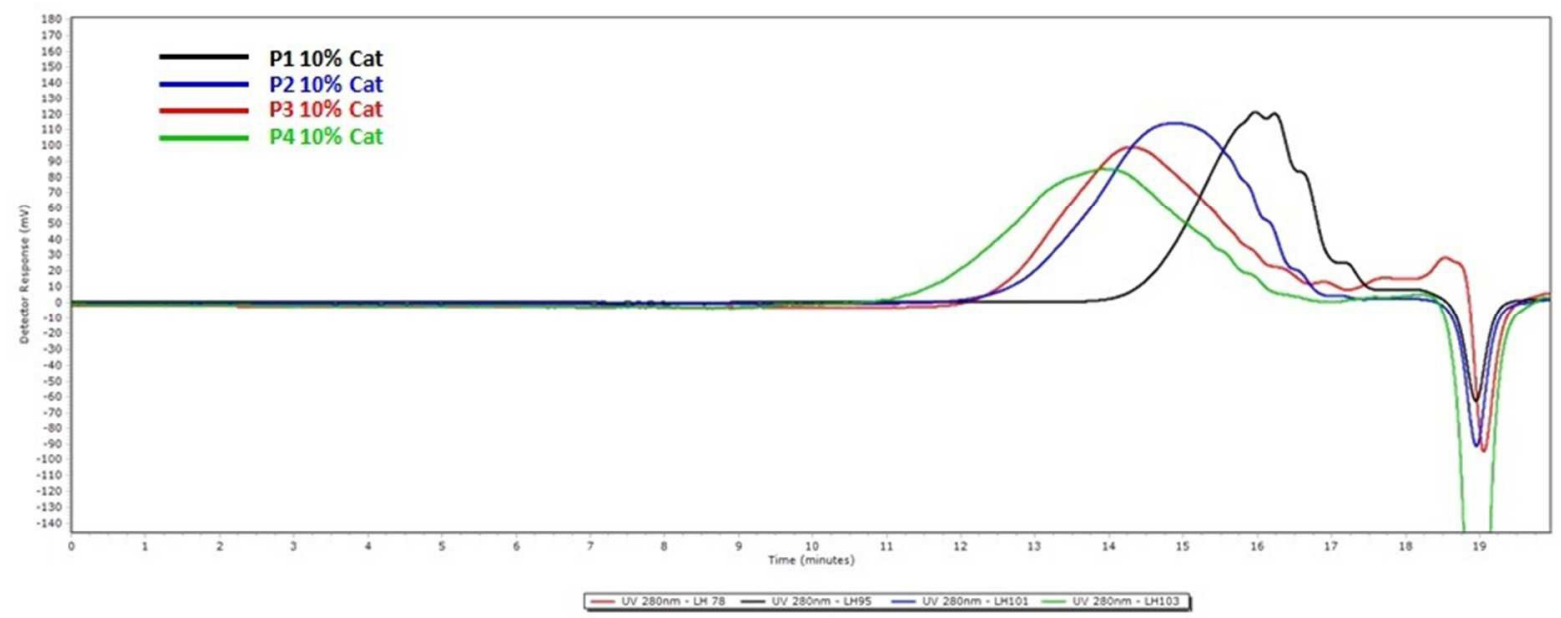

Figure 2. GPC traces of P1, P2, P3 and P4 (10 mol\% catalyst)

of acrylates-, vanillin- and ferulic acid-based $\alpha, \omega$-dienes, respectively. All ADMET reactions were run for 4 hours and followed by GPC in order to identify the best conditions (nature of the $\alpha, \omega$-diene monomer, in mass vs. in solvent, catalyst loading) (Figure 2). Table 1 summarizes the results of these polymerizations. The ${ }^{1} \mathrm{H}$ and ${ }^{13} \mathrm{C}$ NMR spectra of all polymers are displayed in the Supporting Information.

\section{Structural analysis}

In addition to GPC, ${ }^{1} \mathrm{H}$ NMR spectrometry of the resulting crude polymerization mixtures was also performed not only to confirm the polymers structures but also to reveal potential undesired side reactions such as ring-closing metathesis (RCM) or olefin isomerization (Figure 1). ${ }^{1} \mathrm{H}$ NMR spectra of monomers (SYR- 
All (A), SYR-But (B), SYR-Hex (C), SYR-Dec (D)) and their corresponding polymers obtained in mass reveal the decrease of intensity of the signals at 5.0-5.2 and 5.8-5.9 ppm corresponding to the terminal olefin protons along with the formation of the internal double bound whose signal is at $5.5 \mathrm{ppm}$ (See Supporting Information). ADMET polymerizations performed in solvent led to short oligomers (Table 1, Entries 4-6 and 13-15) and higher dispersity (Table 1, Entries 14 and 15), whereas in mass ADMET polymerizations gave higher molecular weights as proven by the GPC results (Table 1, Figure 2). Detailed analyses of ${ }^{1} \mathrm{H}$ and ${ }^{13} \mathrm{C}$ NMR spectra show no evidence of isomerization of the double bond (Supporting information).

On the basis of the results reported in Table 1 and Figure 1, it was concluded that in mass procedure with $1 \mathrm{~mol} \% \mathrm{HG}-\mathrm{II}$, at $100{ }^{\circ} \mathrm{C}$ for 4 hours was the best procedure for ADMET polymerization for all monomers. In such conditions, syringaresinol-based polymers were obtained with $M_{n}$ in the range of 4.5-14.1 kDa.

It is also noteworthy that ADMET polymerization of monomers bearing allyl moieties only provides low molecular weight oligomers. Furthermore, no RCM product was observed in the case of SYR-All, probably because of the ring strain of syringaresinol that prevents intramolecular ring closing metathesis.

Because in solvent ADMET conditions proved unsuitable for our monomers, only results for polymers obtained in mass are being considered in the following discussion (Table 1, Entries 1-3, 7-12 and 16-18). As previously observed in the case of isosorbide based $\alpha, \omega$ dienes, $^{12}$ the rigid bicyclic structure of syringaresinol and its relatively high viscosity

Table 1. Analytical data (GPC, TGA and DSC) of the synthesized polymers via ADMET

\begin{tabular}{|c|c|c|c|c|c|c|c|c|c|c|c|c|}
\hline Entry & $\begin{array}{c}\text { ADMET } \\
\text { conditions }\end{array}$ & $\begin{array}{l}\text { HG-II } \\
\text { (mol\%) }\end{array}$ & Monomer & Polymer & $\begin{array}{c}M_{n} \\
(\mathrm{kDa})\end{array}$ & $\begin{array}{c}M_{w} \\
(\mathrm{kDa})\end{array}$ & $D P_{n}$ & $\oplus_{M}$ & $\begin{array}{c}\text { Conversion }^{\mathrm{c}} \\
(\%)\end{array}$ & $T_{d 5 \%}{ }^{d}\left({ }^{\circ} \mathrm{C}\right)$ & $\begin{array}{c}T_{d 50 \%}{ }^{d} \\
\left({ }^{\circ} \mathrm{C}\right) \\
\end{array}$ & $\begin{array}{l}T_{g}{ }^{\mathrm{e}} \\
\left({ }^{\circ} \mathrm{C}\right)\end{array}$ \\
\hline 1 & In mass ${ }^{b}$ & 1 & SYR-All & & 2.0 & 2.6 & 4 & 1.3 & 59 & 283 & 352 & 65 \\
\hline 2 & In mass ${ }^{b}$ & 5 & SYR-AII & P1 & 2.2 & 2.9 & 4 & 1.3 & 73 & 266 & 327 & 70 \\
\hline 3 & In mass ${ }^{b}$ & 10 & SYR-All & & 2.8 & 3.9 & 6 & 1.4 & 80 & 263 & 343 & 68 \\
\hline 4 & In solvent $^{\mathrm{a}}$ & 1 & SYR-All & & 1.4 & 1.6 & 2 & 1.1 & I & I & 1 & $/$ \\
\hline 5 & In solvent $^{\mathrm{a}}$ & 5 & SYR-All & P1 & 1.6 & 2.1 & 3 & 1.3 & / & / & / & / \\
\hline 6 & In solvent ${ }^{\mathrm{a}}$ & 10 & SYR-All & & 2.2 & 2.8 & 4 & 1.2 & / & / & / & / \\
\hline 7 & In mass ${ }^{b}$ & 1 & SYR-But & & 4.5 & 7.7 & 9 & 1.7 & 93 & 283 & 376 & 58 \\
\hline 8 & In mass ${ }^{b}$ & 5 & SYR-But & P2 & 5.1 & 8.5 & 10 & 1.7 & 88 & 274 & 369 & 60 \\
\hline 9 & In mass ${ }^{b}$ & 10 & SYR-But & & 6.7 & 13.1 & 13 & 1.9 & 89 & 272 & 339 & 61 \\
\hline 10 & In mass ${ }^{b}$ & 1 & SYR-Hex & & 8.9 & 18.3 & 15 & 2.1 & 94 & 308 & 392 & 39 \\
\hline 11 & In mass ${ }^{b}$ & 5 & SYR-Hex & P3 & 8.3 & 15.5 & 14 & 1.9 & 90 & 268 & 342 & 40 \\
\hline 12 & In mass ${ }^{b}$ & 10 & SYR-Hex & & 8.9 & 16.8 & 15 & 1.9 & 86 & 257 & 324 & 38 \\
\hline 13 & In solvent $^{\mathrm{a}}$ & 1 & SYR-Hex & & 1.4 & 1.5 & 2 & 1.1 & I & 1 & I & / \\
\hline 14 & In solvent ${ }^{\mathrm{a}}$ & 5 & SYR-Hex & P3 & 8.4 & 30 & 14 & 3.6 & / & / & / & / \\
\hline 15 & In solvent ${ }^{a}$ & 10 & SYR-Hex & & 8.2 & 26.1 & 14 & 3.2 & / & / & / & / \\
\hline 16 & In mass ${ }^{b}$ & 1 & SYR-Dec & & 13.0 & 25.5 & 19 & 2.0 & 97 & 360 & 393 & 20 \\
\hline 17 & In mass ${ }^{b}$ & 5 & SYR-Dec & P4 & 12.7 & 28.6 & 19 & 2.2 & 95 & 349 & 392 & 19 \\
\hline 18 & In mass ${ }^{b}$ & 10 & SYR-Dec & & 14.1 & 32.0 & 21 & 2.3 & 82 & 347 & 394 & 18 \\
\hline
\end{tabular}

${ }^{\mathrm{a}}$ HG-II (1, 5 or 10 mol\%), 1,4-benzoquinone (2 equivalent relative to HG-II), DCM (2 M), $40{ }^{\circ} \mathrm{C}, 4$ hours; ${ }^{\mathrm{b}} \mathrm{HG}-\mathrm{II}(1,5$ or $10 \mathrm{~mol} \%)$, 1,4-benzoquinone ( 2 equivalent relative to $\mathrm{HG}-\mathrm{II}$ ), vacuum, $100^{\circ} \mathrm{C}, 4$ hours; ${ }^{\mathrm{C}}$ Calculated with the residual monomer amounts determined from the corresponding peak area on SEC traces of crude reaction mixtures prior precipitation; ${ }^{\mathrm{d}}$ TGA data 
recorded at $10{ }^{\circ} \mathrm{C} \cdot \mathrm{min}^{-1}$ under nitrogen $\left(60 \mathrm{~mL} \cdot \mathrm{min}^{-1}\right) ;{ }^{\mathrm{e}} \mathrm{DSC}$ data recorded at $10^{\circ} \mathrm{C} \cdot \mathrm{min}^{-1}$ under nitrogen $\left(60 \mathrm{~mL} \cdot \mathrm{min}^{-1}\right)$, value determined at the $2^{\text {nd }}$ heating scan

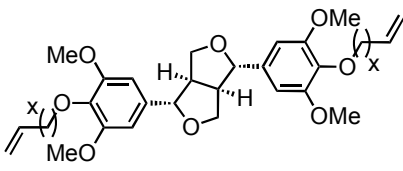

SYR-All ( $\mathrm{x}=1$; syringaresinol)

SYR-But $(x=2$; syringaresinol)

SYR-Hex $(x=4$; syringaresinol)

SYR-Dec $(x=8$; syringaresinol)

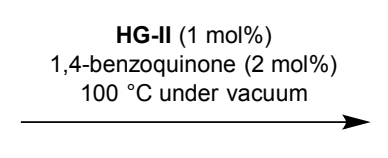

-benzoquinone (2 mol\%)

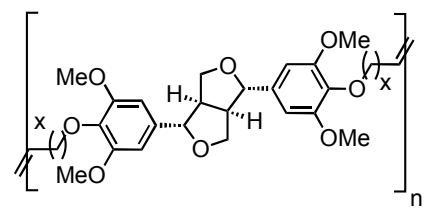

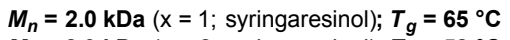
$M_{n}=8.9 \mathrm{kDa}\left(\mathrm{x}=2 ;\right.$ syringaresinol); $T_{g}=58^{\circ} \mathrm{C}$

$M_{n}=8.9 \mathrm{kDa}\left(\mathrm{x}=4 ;\right.$ syringaresinol); $\boldsymbol{T}_{g}=39^{\circ} \mathrm{C}$

$M_{n}=13.0 \mathrm{kDa}(\mathrm{x}=8$; syringaresinol $) ; T_{g}=20^{\circ} \mathrm{C}$

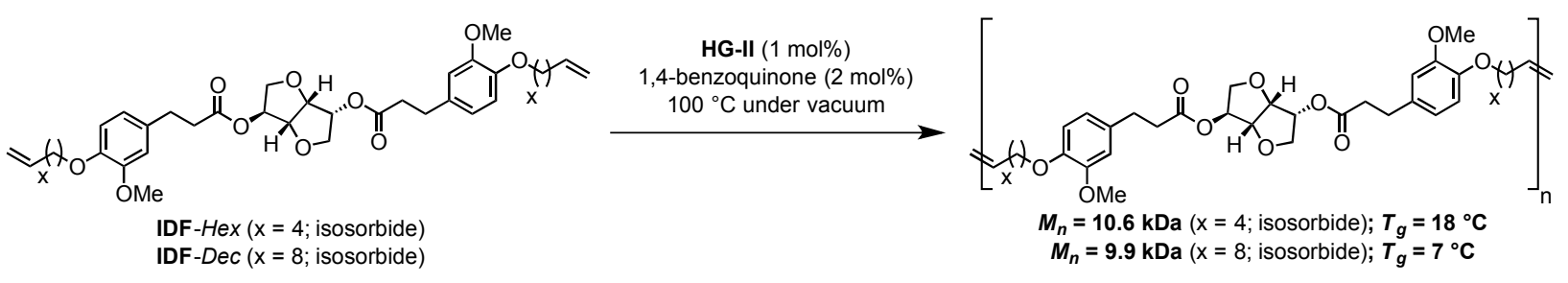

Scheme 2. Syringaresinol- and ferulic acid-derived ${ }^{12}$ polymers via ADMET

restricts the polymerization to a degree of polymerization $\left(D P_{n}\right)$ up to $c a .20$ (Table 1, Entries 16-18). As expected, because of decreasing viscosity, the longer the $\alpha, \omega$-dienes the higher the $M_{n}$ (Table 1, Entries 3, 9, 12 and 18). Interestingly, while molecular weights $\left(M_{n}\right)$ of polymers increase by $98 \%$ when but-1-ene was replaced by hex-1-ene (P3 vs. P2, Table 1, Entries 10 vs. 7), they increase only by $46 \%$ when hex-1-ene is replaced by dec-1-ene (P4 vs. P3, Table 1, Entries 16 vs. 10). Increasing the catalyst loading above $1 \mathrm{~mol} \%$ resulted in similar to slightly higher molecular weights. In the other hand, lower catalyst loadings (e.g., 0.1-0.5 mol\%) did not lead to higher molecular weight, neither did longer reactions times (8 hours vs. 4 hours).

In terms of reactivity, syringaresinol-based $\alpha, \omega$ diene proves as efficient as recently published IDF-Hex and IDF-Dec $\alpha, \omega$-dienes which give similar molecular weights when submitted to ADMET polymerization with HG-II (Scheme 2). ${ }^{12}$

\section{Thermal properties}

Table 2. Thermostability of syringaresinol-based monomers

\begin{tabular}{ccccc}
\hline Monomer & SYR-All & SYR-But & SYR-Hex & SYR-DeC \\
\hline$T_{d 5 \%}\left({ }^{\circ} \mathrm{C}\right)$ & 220 & 273 & 300 & 328 \\
\hline$T_{d 50 \%}\left({ }^{\circ} \mathrm{C}\right)$ & 333 & 334 & 358 & 392 \\
\hline
\end{tabular}

The thermal properties of monomers and polymers described in Table 1 were investigated by thermogravimetric analysis (TGA) and differential scanning calorimetry (DSC).

TGA analyses of the monomers revealed a thermostability $\left(T_{d 50 \%}\right)$ in the range of $333-392{ }^{\circ} \mathrm{C}$ (Table 2). Furthermore, the nature of the alkene impacts the degradation temperature $\left(T_{d}{ }_{50 \%}\right)$. Indeed replacing but-1-ene by dec-1-ene strongly increases their thermostability by $58^{\circ} \mathrm{C}$ (Table 2).

Thermal analyses of polymers P1-P4 showed significant differences in $T_{d(5 \%)}$ and glass transition temperature $\left(T_{g}\right)$ depending on the alkene length $\left(C_{4}, C_{6}\right.$ and $\left.C_{10}\right)$ (Figure $3 \& 4$ ). Because of the presence of aromatic moieties and the rigidity of syringaresinol, all polymers exhibit a thermostability in the range of 257 $360{ }^{\circ} \mathrm{C}\left(T_{d(5 \%)}\right)$, the dec-1-ene based ones being the most stable (Table 1, Entries 16, 17 and 18). 


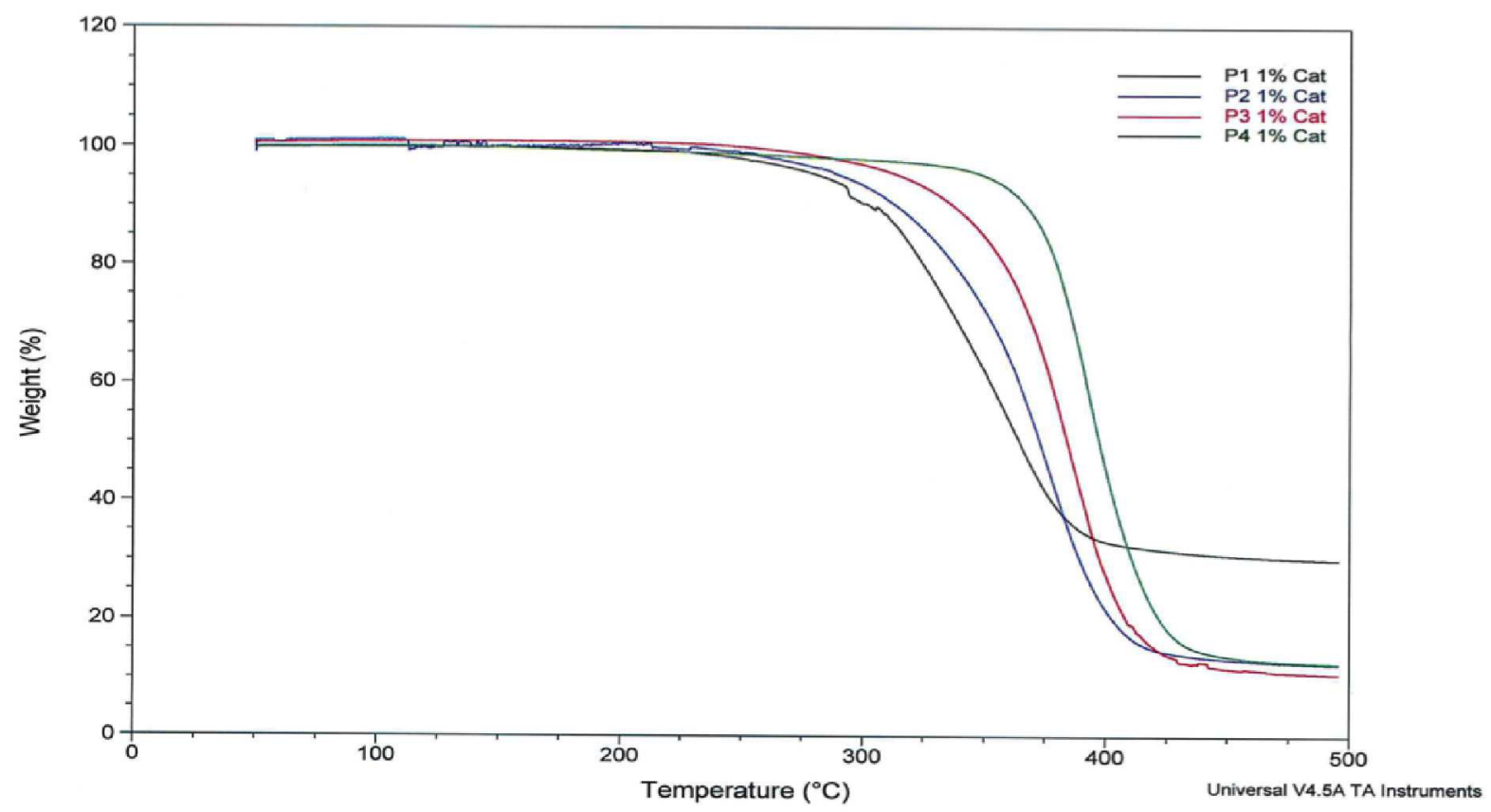

Figure 3. TGA analyses for polymers $\mathbf{P 1}, \mathbf{P 2}, \mathbf{P 3}$, and $\mathbf{P 4}$ (under nitrogen, $10^{\circ} \mathrm{C} \cdot \mathrm{min}^{-1}$ )

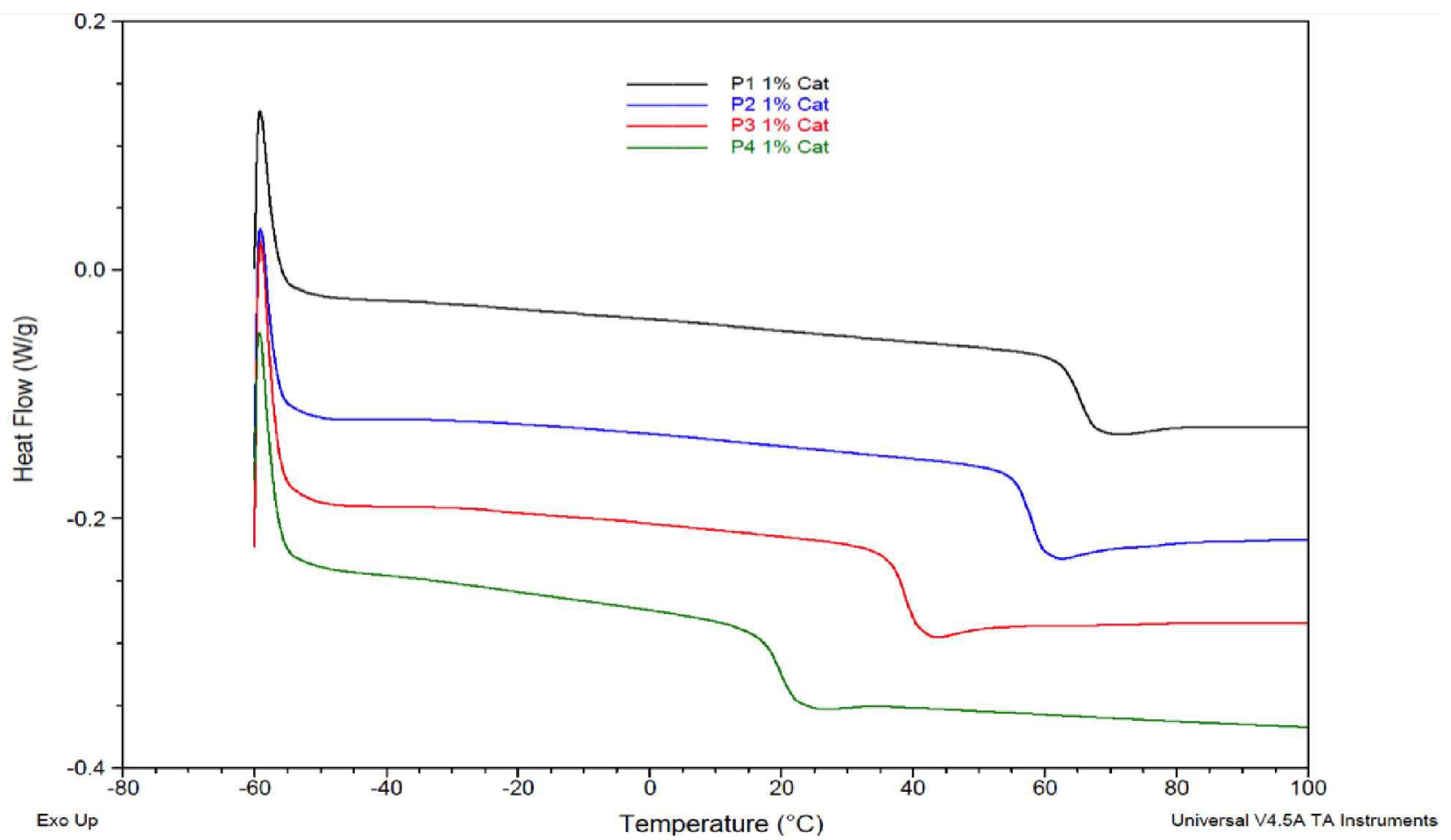

Figure 4. DSC analyses of P1, P2, P3 and P4 ( $2^{\text {nd }}$ heating cycle, under nitrogen, $\left.10^{\circ} \mathrm{C} \cdot \mathrm{min}^{-1}\right)$ 
DSC analyses also reveal that a decrease of the alkene chain length (from decene to butene) results in an inversely proportional increase of the $T_{g}(\mathbf{P} 4<\mathbf{P} 3<\mathbf{P} 2<\mathbf{P} 1)$. Varying the nature of the $\alpha, \omega$-diene monomers thus provides $T_{g}$ in the range of 18 to $70{ }^{\circ} \mathrm{C}$ (Figures $4 \& 5$ ). Compared to IDF-Hex $\alpha, \omega$-diene monomerbased polymer ${ }^{12}$ that exhibits a $T_{g}$ of $18{ }^{\circ} \mathrm{C}$, that of $\mathbf{P 3}$ deriving from SYR-Hex monomer is of 39 ${ }^{\circ} \mathrm{C}$ (Scheme 2). Such an increase could be explained by not only the shorter distance between the two phenols in the $\alpha, \omega$-diene monomer (12 atoms vs. 4 carbon atoms), but also by the presence of extra methoxy groups on the aromatic rings that increases the conformational barriers for chain motion. ${ }^{32}$ Finally, it is noteworthy to mention that all polymers are amorphous and do not show melting points $\left(T_{m}\right)$ on DSC.

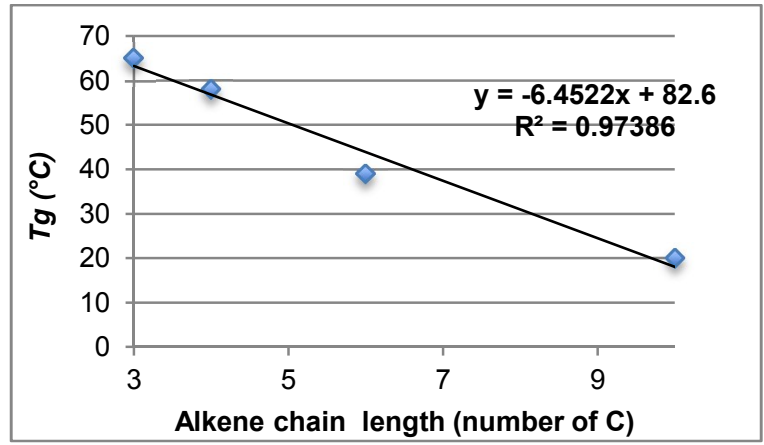

Figure 5. Alkene chain-length dependence of the glass transition temperature $\left(T_{g}\right)$

\section{CONCLUSIONS}

In summary, syringaresinol-based $\alpha, \omega$-diene monomers were obtained in very good yields through a chemo-enzymatic synthetic pathway and were successfully polymerized via ADMET in presence of second generation HoveydaGrubbs catalyst. Mass polymerization resulted in polymers with $M_{n}$ as high as $14.1 \mathrm{kDa}$. Thermal analyses through TGA and DSC demonstrated that these polymers are thermostable up to $257-360{ }^{\circ} \mathrm{C}$ and, more importantly, that their $T_{g}$ can be easily tuned by adjusting the alkene length of the $\alpha, \omega$-diene monomers (from 18 to $70{ }^{\circ} \mathrm{C}$ ). Prepared from renewable feedstocks, these polymers could be envisaged as sustainable substitutes to conventional petro-based polyesters.

\section{ACKNOWLEDGEMENTS}

The authors are grateful to the Region Champagne-Ardenne, the Conseil Général de la Marne and Reims Métropole for their financial support.

\section{REFERENCES AND NOTES}

1. a) J. J. Bozell, J. O. Hoberg, et al. In Green Chemistry - Frontiers in Benign Chemical Synthesis and Processes, Oxford University, 1998, p. 27-45; b) C. Okkerse, H. van Bekkum, Green Chem. 1999, 1, 107; c) D. L. Klass In Biomass for Renewable Energy, Fuels, and Chemicals - Academic Press, 1998, p. 91-157, p. 495-542

2. N. Niciforovic, H. Abramovi, Comp. Rev. Food Sci. F. 2014, 13, 34-51.

3. M. Quentin, V. Allasia, A. Pegard, F. Allais, P.-H. Ducrot, B. Favery, C. Levis, S. Martinet, C. Masur, M. Ponchet, D. Roby, L. Schlaich, L. Jouanin, H. Keller, PLoS Pathog. 2009, 5(1) doi: 10.1371/journal.ppat.1000264

4. F. Allais, M. Aouhansou, A. Majira, P.-H. Ducrot, Synthesis 2010, 16, 2787

5. F. Allais, P.-H. Ducrot, Synthesis 2010, 16, 1649

6. L. M. M. Mouterde, A. L. Flourat, M. M. M. Cannet, P.-H Ducrot, F. Allais, Eur. J. Org. Chem. 2013, 1, 173

7. B. Cottyn, A. Kollman, P. Waffo Teguo, P.H. Ducrot, Chem. Eur. J. 2011, 17, 7282

8. a) J. C. Dean, R. Kusaka, P. S. Walsh, F. Allais, T. S. Zwier, J. Am. Chem. Soc. 2014, 136, 14780; b) L. A. Baker, M. D. Horbury, S. E. Greenough, F. Allais, P. S. Walsh, S. Habershon, and V. G. Stavros, J. Phys. Chem. Lett. 2016, 7, 56-61.

9. F. Pion, A. F. Reano, P.-H. Ducrot and F. Allais, RSC Adv. 2013, 3, 8988

10. F. Pion, P.-H. Ducrot and F. Allais, Macromol. Chem. Phys. 2014, 215, 431 
11. M. Z. Oulame, F. Pion, P.-H. Ducrot, F. Allais, Eur. Polym. J. 2015, 63, 186-193

12. I. Barbara, A. L. Flourat, F. Allais, Eur. Polym. J. 2015, 62, 236-243

13. A. F. Reano, J. Cherubin, A. M. M. Peru, Q. Wang, T. Clément, S. Domenek, F. Allais ACS Sust. Chem. Eng. 2015, 3, 3486-3496

14. A. F. Reano, F. Pion, S. Domenek, P.-HDucrot, F. Allais, Green Chem. 2016, DOI: 10.1039/C6GC00117C

15. A. S. Jaufurally, A. R. S. Teixeira, L. Hollande, F. Allais, P.-H. Ducrot, unpublished results

16. H. Mutlu, L. M. de Espinosa, M. A. R. Meier, Chem. Soc. Rev. 2011, 40, 1404

17. O. Kreye, T. Tóth, M. A. R. Meier, Eur. Polym. J. 2011, 47, 1804

18. H. Mutlu, M. A. R. Meier, Macromol. Chem. Phys. 2009, 210, 1019

19. L. M. de Espinosa, M. A. R. Meier, J. C. Ronda, M.Galià, V. Cadiz, J. Polym. Sci. Part A: Polym. Chem. 2010, 48, 1649

20. T. W. Baughman; K. B. Wagener, Adv. Polym. Sci. 2005, 176, 1

21. O. Türünç, L. M. de Espinosa, M. A. R. Meier, Macromol. Rapid. Commun. 2011, 32, 1357
22. S. Günther, P. Lamprecht, G. A. Luinstra, Macromol. Symp. 2010, 293, 15

23. M. Firdaus, M. A. R. Meier, Eur. Polym. J. 2013, 49, 156

24. A. Llevot, E. Grau, S. Carlotti, S. Grelier, H. Cramail, Polym. Chem. 2015, 6, 7693-7700

25. T. Lebarbé, A. S. More, P. S. Sane, E. Grau, C. Alfos, and H. Cramail, Macromol. Rapid Commun. 2014, 35, 479-483

26. T. Lebarbé, M. Neqal, E. Grau, C. Alfos and H. Cramail, Green Chem. 2014, 16, 17551758

27. A. Llevot, E. Grau, S. Carlotti, S. Grelier and H. Cramail, Eur. Polym. J. 2015, 67, 409-417

28. M. D. Watson, K. B. Wagener, Macromolecules 2000, 33, 8963

29. M. D. Schulz, K. B. Wagener, ACS Macro Lett. 2012, 1, 449

30. S. H. Hong, D. P. Sanders, C. W. Lee, R. H. Grubb, J. Am. Chem. Soc. 2005, 31, 368

31. M. Abbas, C. Slugovc, Tetrahedron Lett. 2011, 52, 2560

32. H. T. H. Nguyen, M. H. Reis, P. Qi and S. A. Miller, Green Chem. 2015, 17, 4512. 


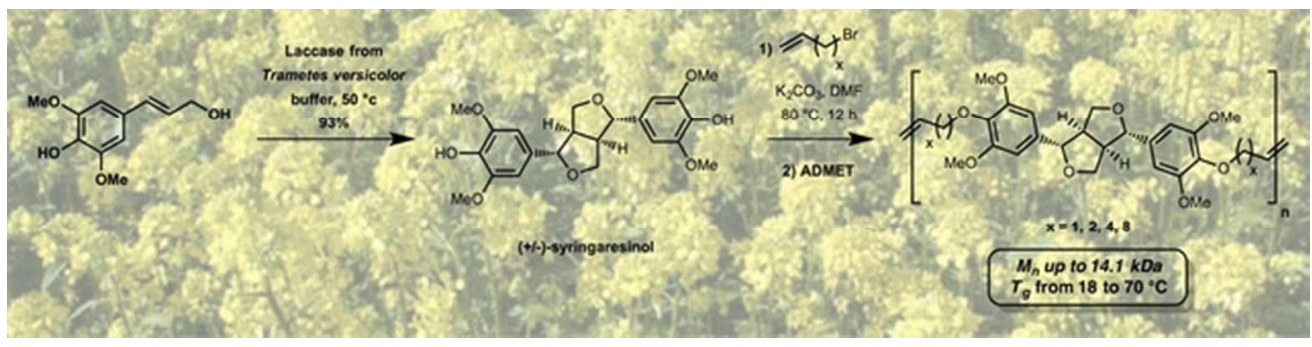

$54 \times 13 \mathrm{~mm}(300 \times 300 \mathrm{DPI})$ 